\section{The Acidification of Sphagnum Moss Substrate during Phalaenopsis Cultivation}

\author{
Wan-Yi Yen ${ }^{1}$ and Yao-Chien Alex Chang, ${ }^{2,4}$ \\ Department of Horticulture, National Taiwan University, 1 Roosevelt Road \\ Sec. 4, Taipei 10617, Taiwan
}

\author{
Yin-Tung Wang ${ }^{3}$ \\ Department of Horticultural Sciences, Texas A\&M University, College \\ Station, TX 77843
}

Additional index words. $\mathrm{pH}$, electrical conductivity, orchids, fertilization, rhizosphere

\begin{abstract}
Sphagnum moss has been used as the major substrate for cultivating Phalaenopsis spp. in China, Japan, and Taiwan. With a lengthened duration of cultivation, the $\mathbf{p H}$ of the moss gradually declines. It is not understood what causes this decline in substrate pH. Using the vegetatively propagated $\mathbf{P h a l}$. Sogo Yukidian 'V3', this study investigated if substrate, fertilization, light, and plant roots could be the cause of $\mathrm{pH}$ decline in the substrate. The results showed that, although increasing fertilizer concentration resulted in a low initial pH (pH measured by the pour-through technique at first fertilization), fertilization itself was not the primary cause of the long-term $\mathrm{pH}$ decline. Regardless of whether the sphagnum moss was fertilized, the $\mathrm{pH}$ of the substrate without plants increased as time progressed, whereas the $\mathrm{pH}$ of the substrate in which living Phalaenopsis plants were growing declined with time. Although the magnitude and course of $\mathrm{pH}$ decline were different in various substrates, the pH of sphagnum moss, artificial textile fiber, and pine bark substrates in which living plants were growing declined with time. Whether the substrate was exposed to light (clear pots) or not (opaque pots) had no effect on substrate $\mathrm{pH}$, indicating that algae were not a factor in pH decline. Therefore, the roots of Phalaenopsis may be the major contributor to substrate $\mathrm{pH}$ decline during production.
\end{abstract}

Phalaenopsis has become one of the most important floral crops in the world. It is the highest valued potted plant sold at auctions in The Netherlands and the most valued potted flowering plant in the United States (United States Department of Agriculture, 2010). In Taiwan, the export value of Phalaenopsis increased from $\$ 64.0$ million in 2009 to $\$ 82.6$ million in 2010 (Bureau of Foreign Trade,

Received for publication 10 Feb. 2011. Accepted for publication 30 May 2011.

Financial support was provided by the Agriculture and Food Agency, Council of Agriculture [100AS-4.2.2-FD-Z3(16)].

This article is a part of a M.S. thesis of the first author. We thank Dr. Ren-Shih Chung of National Taiwan University, Taiwan, for his expertise and time spent in a fruitful discussion with the authors. We also thank R.M. Hsieh of Taiwan Sugar Corporation, Taiwan, for lending the bioreactors and Dr. Keng-Heng Chang of Agricultural Research Institute, Taiwan, for providing the artificial textile fiber.

${ }^{1}$ Former Graduate Student.

${ }^{2}$ Associate Professor.

${ }^{3}$ Professor, Texas A\&M University System Agricultural Research and Extension Center, Weslaco (retired). Currently, Adjunct Professor, Department of Horticultural Sciences, Texas A\&M University, College Station, TX. Director of R\&D/Production, Matsui Nursery, Salinas, CA.

${ }^{4}$ To whom reprint requests should be addressed; e-mail alexchang@ntu.edu.tw.
2011), a 29\% annual growth, with increasing quantities being exported.

Wang and Konow (2002) showed the influence of root substrate and fertilizer on substrate $\mathrm{pH}$. The addition of $20 \%$ sphagnum peat to fir bark resulted in a lower initial $\mathrm{pH}$ and more severe decline in substrate $\mathrm{pH}$ than fir bark alone (Wang, 1998; Wang and Konow, 2002). Since the late 1980 s, sphagnum moss has been used as the sole substrate for producing Phalaenopsis in Taiwan. Previous research showed that the $\mathrm{pH}$ of the moss in Phalaenopsis containers declines over time (Chen, 2006; Lei, 2007; Peng, 2008; Yao, 2007; $\mathrm{Yu}, 2004)$. Some orchid growers consider that this drop in $\mathrm{pH}$ may be caused by the decomposition of the moss. However, the decline in substrate $\mathrm{pH}$ during production may be the result of the characteristics of the moss, fertilizer applications, and the presence of roots.

The nature of the root substrate affects initial $\mathrm{pH}$ value and determines the degree of acidification during production. Tsai (2000) grew Oncidium Gower Ramsey in coconut husks, tree fern roots, sphagnum moss, or a mixture of these materials and found acidification ( $\mathrm{pH}$ decline) in all of these substrates. Coconut husks and tree fern roots had higher initial $\mathrm{pH}$ and the decline in $\mathrm{pH}$ was less than the other two. Sphagnum moss had the lowest initial $\mathrm{pH}$ of 4.2 and the mixture of the three materials had the most acidification with $\mathrm{pH}$ dropping from 5.9 to 3.1. Previous research showed that, as fertilizer concentration in- creased, $\mathrm{pH}$ of the root substrate declined (Kowalczyk et al., 2008; Wang, 1996, 2010). In general, repeated applications of a fertilizer having nitrate as its main nitrogen $(\mathrm{N})$ source causes root substrate $\mathrm{pH}$ to rise, whereas one having its $\mathrm{N}$ mainly from ammonium or urea leads to lower pH (Argo and Biernbaum, 1997; Argo and Fisher, 2002; Peng, 2008; Pinton et al., 2007).

Other than anchoring the plant and absorbing water and nutrients, roots also release organic and inorganic substances to alter the rhizosphere. The tendency to secrete such substances and the type of substances released are affected by a number of factors such as plant species and nutrient concentration (Pinton et al., 2007). As the plant releases exudates to the rhizosphere through anion channels, the $\mathrm{H}^{+}$-ATPase on cell membrane discharges a proton to balance the electrical charge, causing the $\mathrm{pH}$ of the rhizosphere to decline (Kollmeier et al., 2001; Neumann et al., 1999; Sakaguchi et al., 1999).

The objective of this study was to determine the effects of fertilizer, characteristics of substrates, light exposure to substrate, and plant species on the change of substrate $\mathrm{pH}$ during the production of Phalaenopsis. An oncidium (Oncidium Sw.) hybrid was used in one experiment to determine if there was a difference among orchid species in causing the $\mathrm{pH}$ decline in the sphagnum moss substrate.

\section{Materials and Methods}

Plant materials. Except for Expt. 5, all other experiments used Phalaenopsis Sogo Yukidian 'V3' plants that were 16 months out of the flask and planted in sphagnum moss in soft, clear plastic pots. These plants were removed from their original $10.5-\mathrm{cm}$ pots, cleaned of the moss, and replanted in $10.5-\mathrm{cm}$ pots (825 mL in vol.) that were filled with moist Chilean sphagnum moss (200 g fresh weight/ pot; $25 \mathrm{~g}$ dry weight/pot). The moss was soaked overnight in tap water and the excess water was removed in a spin-drying machine at $1200 \mathrm{rpm}$ for $1 \mathrm{~min}$. Plants were placed and grown in a greenhouse with pad and fan cooling. The average day/night temperatures were 23.2/ $21.1^{\circ} \mathrm{C}$ and the average photosynthetic photon flux was $165 \mu \mathrm{mol} \cdot \mathrm{m}^{-2} \cdot \mathrm{s}^{-1}$ when measured between $1100 \mathrm{HR}$ and $1300 \mathrm{HR}$.

A $15.0 \mathrm{~N}-2.2 \mathrm{P}-12.5 \mathrm{~K}$ water-soluble fertilizer (Peters Excel 15-5-15 Cal-Mag; The Scotts Co., Marysville, $\mathrm{OH}$ ) was used at a rate of $0.67 \mathrm{~g} \cdot \mathrm{L}^{-1}\left(100 \mathrm{mg} \cdot \mathrm{L}^{-1} \mathrm{~N}\right)$ in Expt. 3, whereas $1.33 \mathrm{~g} \cdot \mathrm{L}^{-1}\left(200 \mathrm{mg} \cdot \mathrm{L}^{-1} \mathrm{~N}\right)$ was used in all other experiments. The $\mathrm{pH}$ value of the fertilizer solution was adjusted to 6.0 with $\mathrm{NaOH}$ before application, resulting in electrical conductivity (EC) values of 0.7 and $1.4 \mathrm{dS} \cdot \mathrm{m}^{-1}$ for $0.67 \mathrm{~g} \cdot \mathrm{L}^{-1}$ and $1.33 \mathrm{~g} \cdot \mathrm{L}^{-1}$ of the fertilizer, respectively. This fertilizer contained (by weight), among other nutrients, $1.20 \%$ ammonium, $11.75 \%$ nitrate, $2.05 \%$ urea, $5 \%$ soluble calcium, and $2 \%$ soluble magnesium. Plants were fertigated when the substrate became dry; no additional irrigation was given between fertigations.

The pour-through technique for the collection of leachate samples from the root substrate 
followed that of Yao et al. (2008). Sixty milliliters of distilled water was poured evenly over the surface of the moss in pots $30 \mathrm{~min}$ after fertigating. A pH meter (Microcomputer $\mathrm{pH} / \mathrm{mv} / \mathrm{TEMP}$ meter 6171; JENCO, Portland, $\mathrm{OR}$ ) and a conductivity meter (IQ170; IQ Scientific Instruments, Carlsbad, CA) were used for measuring the $\mathrm{pH}$ and $\mathrm{EC}$, respectively, of the collected leachate samples.

Expt. 1: Effects of the presence of plants and fertilization on acidification of the sphagnum moss. This experiment was a $2 \times 2$ factorial arrangement having two fertilizer treatments (with or without fertilization) each with or without a plant in the pot. The four treatment combinations were 1) with a plant and fertilization (Phal.+/Fer.+); 2) no plant but with fertilization (Phal.-/Fer.+); 3) with a plant but no fertilization (Phal.+/Fer.-); and 4) no plant and no fertilization (Phal.-/Fer.-). Plants that were fertilized were given $200 \mathrm{~mL}$ of a solution containing $1.33 \mathrm{~g} \cdot \mathrm{L}^{-1}$ of the $15.0 \mathrm{~N}-2.2 \mathrm{P}$ $12.5 \mathrm{~K}$ fertilizer every 3 weeks. Those that were not fertilized were given distilled water at the same amount and frequency. Leachate samples were collected by the pour-through technique 30 min after fertilization or watering. Each treatment had 12 single-pot replications. This experiment lasted for 30 weeks.

Expt. 2: Effects of light exclusion, presence of plants, and fertilizer application on substrate acidification. Sphagnum moss that received fertilizer in Expt. 1 (Fer.+) had more algae; therefore, light exclusion was imposed to determine if algae had any effect on $\mathrm{pH}$ decline in the moss substrate. This experiment was a $2 \times$ $2 \times 2$ factorial combination of the presence or absence of light (light and darkness), with or without fertilization (Fer.+ and Fer.-), and the presence or absence of a plant in pot (Phal.+ and Phal.-) for a total of eight treatments. Clear, soft plastic pots $10.5 \mathrm{~cm}$ in diameter were used for the light treatment, whereas similar pots made of black plastic were used for the darkness treatment. A single pot represented an experimental unit that was replicated 12 times per treatment. The substrate surface was covered with aluminum foil with several small holes to prevent light from reaching the moss surface and yet allow for water evaporation. The cultural practices were similar to that of Expt. 1. Pots were fertilized or watered every 6 weeks as a result of the slow water loss. Leachate samples were collected $30 \mathrm{~min}$ after fertigation for $\mathrm{pH}$ and EC determinations. This experiment lasted for 24 weeks.

Expt. 3: Effects of plant and nutrient solution on solution $p H$. This experiment used short-term hydroponic culture as a tool to determine the effect of roots on $\mathrm{pH}$. This would eliminate the possible effect of moss on substrate $\mathrm{pH}$. An air-driven periodic immersion bioreactor (Development Center for Biotechnology, Taipei, Taiwan) was used as the hydroponic culture container. To support the plant and to avoid root rot resulting from long periods of soaking in water, $400 \mathrm{~g}$ of glass beads (Guo-Zhou Ltd. Co., Taipei, Taiwan) 6 to $9 \mathrm{~mm}$ in diameter were placed at the bottom of each container. The experimental design was similar to that of Expt.1, except there was no moss. There were four treatments in total (with or without a plant in the bioreactor and with or without fertilization) and each treatment consisted of a single bioreactor that was replicated six times.

Plants that received fertilization were given a nutrient solution that contained $0.67 \mathrm{~g} \cdot \mathrm{L}^{-1}$ of a $15.0 \mathrm{~N}-2.2 \mathrm{P}-12.5 \mathrm{~K}$ fertilizer, whereas those receiving no fertilization received distilled water at each irrigation. Both the nutrient solution and distilled water were adjusted to $\mathrm{pH} 6$ with $\mathrm{NaOH}$. At the onset of this experiment, plastic bottles were filled with $500 \mathrm{~mL}$ of the nutrient solution or water, which were wrapped with aluminum foil to keep out light, for the entire experimental period. The original growing substrate was removed and deteriorated roots were trimmed off, and then the plants were washed under running tap water to completely remove the sphagnum moss. The roots were then immersed in distilled water for $30 \mathrm{~min}$ and allowed to air-dry overnight. The root system was immersed in the designated liquid for $30 \mathrm{~min}$ each and every day between $1500 \mathrm{HR}$ and $1600 \mathrm{HR}$. Two hours after the drained and recovered liquid was collected, the $\mathrm{pH}$ and EC were determined. The treatments were continued for $23 \mathrm{~d}$.

Expt. 4: Acidification of various growing substrates. Plants were cultured in sphagnum moss (SM), artificial textile fiber (TF; artificial moss), or processed bark of Pinus radiata (PB; Orchiata, No. 5; Pacific Wide Group, Christchurch, New Zealand) to investigate the effect of substrate on the acidification. Textile fiber is a waste product from the manufacture of textile using an equal volume mixture of polyamide (nylon 6) and polyethylene terephthalate and consists of loosely twisted threads (Chang et al., 2006). All materials were soaked in water overnight. Sphagnum moss and TF were dried by spinning for $1 \mathrm{~min}$ in a spin-drying machine at $1200 \mathrm{rpm}$. Excess water was drained off of the bark before planting. All plants were fertigated every 3 weeks. Pots that were filled with bark became dry after 5 to $6 \mathrm{~d}$ and were given distilled water but not so much as to cause leaching. This experiment lasted for 27 weeks.

Expt. 5: Genus effect on substrate acidification. This experiment was to elucidate if plant species contributes to substrate acidification. Vegetatively propagated plants of $\mathrm{Pha}$ laenopsis Sogo Yukidian 'V3' (average fresh weight $275 \mathrm{~g}$ ) and Oncidium Gower Ramsey (five pseudobulbs and $322 \mathrm{~g}$ in average fresh weight) were planted in $10.5-\mathrm{cm}$ soft, clear plastic pots that were filled with Chilean sphagnum moss. Pots that were filled with moss, but had no plants, were used as controls. Fertigation was applied every 3 weeks and this experiment lasted for 18 weeks. Each treatment had 12 single-pot replications.

Experimental design and statistical analysis. All experiments were conducted in a completely randomized design. Data were analyzed with Costat 6.303 (CoHort Software, Monterey, CA) using analysis of variance. Figures were made with SigmaPlot 10.0 (Systat Software Inc., Chicago, IL).

\section{Results}

Expt. 1: Effects of presence of plants and fertilization on acidification of the sphagnum moss. The initial $\mathrm{pH}(\mathrm{pH}$ measured by the pour-through technique at the first fertilization) for Phal.-/Fer.- was 4.8 and declined to 3.9 in Week 12 but fluctuated between $\mathrm{pH} 4.1$ and 5.3 between Weeks 12 and 30 (Fig. 1A). Phal.+/Fer.- had a starting $\mathrm{pH}$ of 5.0 that declined to 3.2 in Week 12 and fluctuated between 3.4 and 4.0 thereafter with an end pH of 3.5 (Fig. 1A). Phal.-/Fer.+ had a low initial $\mathrm{pH}$ of 3.7 and it fluctuated between 3.4 and 3.7 until the end of this experiment (Fig. 1A). Phal.+/Fer.+ had a starting $\mathrm{pH}$ of 3.7 that dropped to 2.9 in Week 15 and remained at this level until Week 30 (Fig. 1A). These results showed that fertilization $($ Fer. + ) resulted in lower initial $\mathrm{pH}$ of the moss substrate and the presence of plants (Phal.+) caused a faster and more severe acidification than moss without a plant (Phal.-).

Fertilization (Fer.+) resulted in high starting EC of $1.33 \mathrm{dS} \cdot \mathrm{m}^{-1}$ in the moss (Fig. 1B). Beginning in Week 6, the EC of Phal.-/Fer.+ exceeded that of Phal.+/Fer.+, reaching 1.87 $\mathrm{dS} \cdot \mathrm{m}^{-1}$ by Week 30 (Fig. 1B). The EC of Phal.-/Fer.+ increased with time, indicating the accumulation of salts after each fertigation. The EC of Phal.+/Fer.+ went up to 1.60 $\mathrm{dS} \cdot \mathrm{m}^{-1}$ in Week 6 but declined in Week 9 and reached $1.27 \mathrm{dS} \cdot \mathrm{m}^{-1}$ in Week 30 , lower than that of Phal.-/Fer.+ (Fig. 1B). The decrease in EC over time in fertilized pots reflects the likely uptake of nutrient ions by the plant
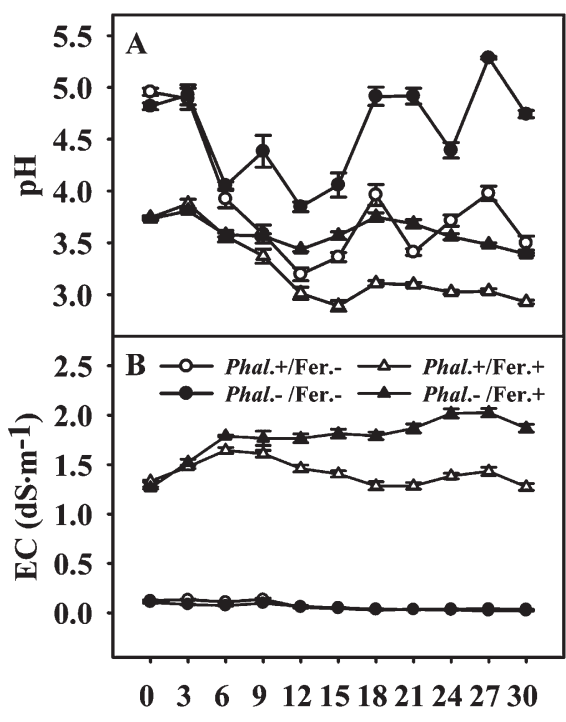

Time after treatment (Weeks)

Fig. 1. Changes in $\mathrm{pH}$ (A) and electrical conductivity (EC) (B) values in sphagnum moss as affected by planting Phalaenopsis Sogo Yukidian 'V3' and fertilizer application (1.33 $\mathrm{g} \cdot \mathrm{L}^{-1}$ Peters Excel 15.0N-2.2P-12.5K Cal-Mag). "Phal.+/Fer.-" means with Phalaenopsis planted and without fertilization. "Phal.-/Fer.-" means without Phalaenopsis planted and without fertilization. "Phal.+/Fer.+" means with Phalaenopsis planted and with fertilization. "Phal.-/Fer.+" means without Phalaenopsis planted and with fertilization. Bars indicate SE of the means; $n=12$. 
rather than adsorption by the substrate or losses through leaching, especially when compared with pots in which there were no plants. Electrical conductivities for the two Fer.treatments were $0.12 \mathrm{dS} \cdot \mathrm{m}^{-1}$ initially and ended at $0.04 \mathrm{dS} \cdot \mathrm{m}^{-1}$ (Fig. 1B).

Expt. 2: Effects of light exclusion, presence of plants, and fertilizer application on substrate acidification. The results showed that the initial $\mathrm{pH}$ of the substrate receiving fertilization (3.4) was lower than that of the substrate given only water (4.1). Regardless of fertilization or exposure to light, pots having a plant all had lower $\mathrm{pH}$ than those without. Substrate acidification was not observed in pots without a plant (data not shown). Plants in clear pots that were exposed to light had greater root number and root dry weight of $6.3 \mathrm{~g}$, whereas those in black pots that were covered with foil had fewer roots with a dry weight of $4.0 \mathrm{~g}$ (data not shown), suggesting that light possibly promoted root growth. However, light and the presence of algae had no effect on substrate $\mathrm{pH}$ at Week 24 (Table 1). The presence of plants or fertilization caused the $\mathrm{pH}$ of the moss substrate to decline.

Expt. 3: Effects of plant and nutrient solution on solution $\mathrm{pH}$. The initial $\mathrm{pH}$ of the Phal.--Fer-- solution was 7.1, which gradually increased to 7.6 at the end of this experiment (Fig. 2A). The Phal.+/Fer.- treatment had a starting $\mathrm{pH}$ of 6.6 and the $\mathrm{pH}$ dropped to 6.4 by Day 12 (Fig. 2A). The $\mathrm{pH}$ for Phal.-/Fer.+ started at 6.6 and increased with time to a final $\mathrm{pH}$ of 7.0. The $\mathrm{pH}$ in bioreactors that had a plant and were fertilized began at 6.5 that declined to 6.1 after $18 \mathrm{~d}$ (Fig. 2A). These results strongly suggest that the presence of roots resulted in the $\mathrm{pH}$ decline in the bioreactor nutrient solution.

The EC of the nutrient solution was 0.73 $\mathrm{dS} \cdot \mathrm{m}^{-1}$ for all fertilization treatments at the onset of this experiment. By the time the experiment was ended, solution EC increased to $0.96 \mathrm{dS} \cdot \mathrm{m}^{-1}$ regardless of whether there was a plant in the bioreactor (Fig. 2B). The increase of EC is probably caused by salt residue left from solution evaporation. The initial solution EC for the two treatments that did not receive fertilizer was $0.02 \mathrm{dS} \cdot \mathrm{m}^{-1}$ that increased to $0.16 \mathrm{dS} \cdot \mathrm{m}^{-1}$ in bioreactors with a plant and to $0.10 \mathrm{dS} \cdot \mathrm{m}^{-1}$ in bioreactors without a plant.

Table 1. The analysis of variance for effects of light, Phalaenopsis planting, and fertilization on substrate acidification.

\begin{tabular}{|c|c|c|c|c|c|c|}
\hline \multirow{2}{*}{$\begin{array}{l}\text { Source } \\
\text { Main effects }\end{array}$} & \multirow[t]{2}{*}{$\mathrm{df}$} & \multirow[t]{2}{*}{ Type III SS } & \multirow[t]{2}{*}{ MS } & \multirow[t]{2}{*}{$\mathrm{F}$} & \multicolumn{2}{|c|}{$P$} \\
\hline & & & & & & \\
\hline Light & 1 & 0.094940 & 0.094940 & 1.1773 & 0.281 & NS \\
\hline Phal. & 1 & 18.134939 & 18.134939 & 224.8898 & $<0.001$ & $* * *$ \\
\hline Fer. & 1 & 6.135195 & 6.135194 & 76.0820 & $<0.001$ & *** \\
\hline \multicolumn{7}{|l|}{ Interaction } \\
\hline Light*Phal. & 1 & 1.224310 & 1.224310 & 15.1866 & $<0.001$ & *** \\
\hline Light*Fer. & 1 & 0.908242 & 0.908242 & 11.2630 & 0.001 & $* *$ \\
\hline Phal.*Fer. & 1 & 4.806800 & 4.806800 & 59.6087 & $<0.001$ & *** \\
\hline Light*Phal.*Fer. & 1 & 0.452311 & 0.452311 & 5.6091 & 0.020 & $*$ \\
\hline Error & 85 & 6.854334 & 0.080639 & & & \\
\hline Total & 92 & 38.979406 & & & & \\
\hline
\end{tabular}

Expt. 4: Acidification of various growing substrates. The initial $\mathrm{pH}$ values of $\mathrm{SM}, \mathrm{TF}$, and $\mathrm{PB}$ were $3.9,6.4$, and 4.8 , respectively (Fig. 3A). By Week 27, the $\mathrm{pH}$ of SM dropped to 2.9 , a decline of one $\mathrm{pH}$ unit and the lowest $\mathrm{pH}$ among the three substrates. The $\mathrm{pH}$ in TF declined quickly by more than two $\mathrm{pH}$ units to 3.9 by Week 27 . The magnitude of acidification in PB (from 4.8 to 4.2 ) was less than in the other two substrates (Fig. 3A).

The substrate EC was lowest in PB and changed little during the experiment (Fig. $3 \mathrm{~B})$. EC in SM and TF gradually increased during the first 6 weeks and that became higher in SM after Week 12. At the end of this experiment, SM had an average EC of 1.8 $\mathrm{dS} \cdot \mathrm{m}^{-1}$, whereas TF had an EC of $1.55 \mathrm{dS} \cdot \mathrm{m}^{-1}$.

Expt. 5: Genus effect on substrate acidification. No acidification was observed in the $\mathrm{SM}$ without a plant, in which the $\mathrm{pH}$ increased slightly from 3.7 at the beginning to 4.0 after 18 weeks (Fig. 4A). The pH of SM with a Phalaenopsis planted declined from 3.6 at the onset of this experiment to 3.3 at the end. The $\mathrm{pH}$ of the SM with Oncidium increased slightly from 3.6 to 3.9 by Week 9 but then declined to 3.3 by the end of this experiment (Fig. 4A).

As time progressed, substrate solution EC of all three groups gradually increased (Fig. 4B). This is particularly true for the substrate without a plant, increasing from 1.09 initially to $1.93 \mathrm{dS} \cdot \mathrm{m}^{-1}$ at the end. The EC of the SM with Phalaenopsis reached $1.44 \mathrm{dS} \cdot \mathrm{m}^{-1}$ and that with Oncidium increased to $1.67 \mathrm{dS} \cdot \mathrm{m}^{-1}$ at the end (Fig. 4B).

\section{Discussion}

Drop of pH of SM substrate over time is commonly observed in the cultivation of Phalaenopsis. Factors that may cause the acidification of the moss include fertilizer application, characteristics of the substrate, and the physiological nature of the plant itself. The results from these five experiments are used to discuss the major cause of substrate acidification and the other factors involved.

Whether there was a Phalaenopsis plant in the pot or not, the initial $\mathrm{pH}$ of the moss was always lower with fertilization than without (Fig. 1A). Yao (2007) also showed that as fertilizer concentration increased, $\mathrm{pH}$ of the moss after the initial fertilization declined more. This may be the result of the ion exchange between the substrate and the nutrient solution. Sphagnum moss is a natural material, which has numerous negatively charged sites that attract $\mathrm{H}^{+}$. On fertilizing, the cations

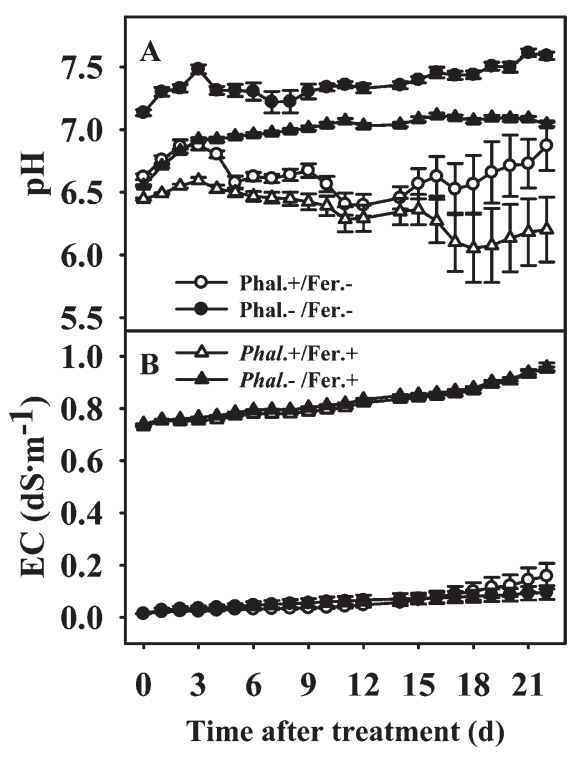

Fig. 2. Changes in $\mathrm{pH}(\mathbf{A})$ and electrical conductivity (EC) (B) values in hydroponic solution as affected by planting Phalaenopsis Sogo Yukidian 'V3' and fertilizer application $\left(0.67 \mathrm{~g} \cdot \mathrm{L}^{-1}\right.$ Peters Excel 15-5-15 Cal-Mag). "Phal.+/Fer.-" means with Phalaenopsis planted and without fertilization. "Phal.-/Fer.-" means without Phalaenopsis planted and without fertilization. "Phal.+/Fer.+" means with Phalaenopsis planted and with fertilization. "Phal.-/Fer.+" means without Phalaenopsis planted and with fertilization. Bars indicate SE of the means; $\mathrm{n}=6$.

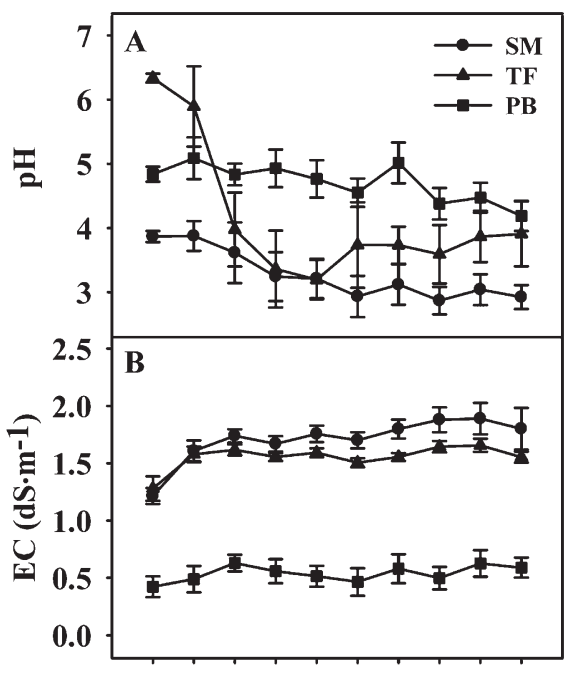

$\begin{array}{llllllllll}0 & 3 & 6 & 9 & 12 & 15 & 18 & 21 & 24 & 27\end{array}$

Time after treatment (Weeks)

Fig. 3. Changes in substrate $\mathrm{pH}(\mathbf{A})$ and electrical conductivity (EC) (B) as affected by planting Phalaenopsis Sogo Yukidian 'V3' with three substrates. $\mathrm{SM}=$ sphagnum moss; $\mathrm{TF}=$ artificial textile fiber; $\mathrm{PB}=$ pine bark. Bars indicate SE of the means; $n=20$. 


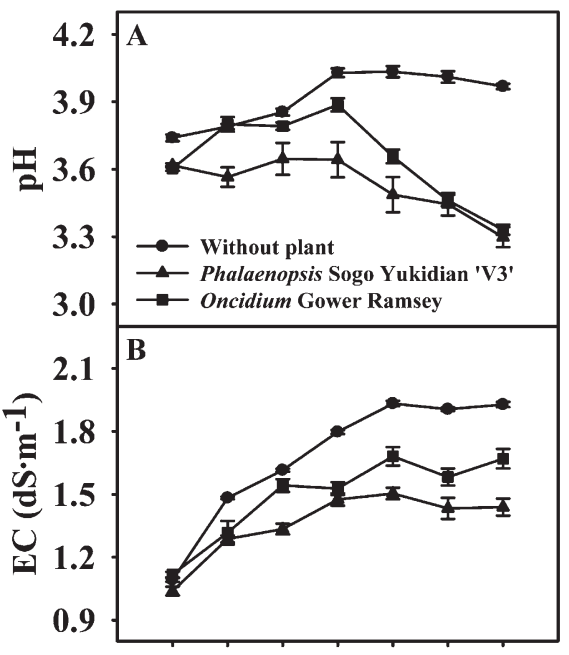

$\begin{array}{llllllll}0 & 3 & 6 & 9 & 12 & 15 & 18\end{array}$

Time after treatment (Weeks)

Fig. 4. Changes in substrate $\mathrm{pH}(\mathbf{A})$ and electrical conductivity (EC) (B) in sphagnum moss as affected by orchid species. Bars indicate SE of the means; $\mathrm{n}=12$.

in the fertilizer replace the $\mathrm{H}^{+}$on these sites. Therefore, as fertilizer concentration increases, more $\mathrm{H}^{+}$is released by the moss, causing the $\mathrm{pH}$ of the moss substrate to decline more.

Peters Excel 15.0N-2.2P-12.5K watersoluble fertilizer was used in this study. Seventy-eight percent of the $\mathrm{N}$ in this fertilizer is in the nitrate form; therefore, it is a basic fertilizer. Prolonged use of a basic fertilizer high in nitrate caused the substrate $\mathrm{pH}$ to increase (Argo and Fisher, 2002). This is the result of cotransportation of $\mathrm{H}^{+}$by roots as nitrate ions are absorbed to elevate substrate $\mathrm{pH}$. On the contrary, when roots absorb ammonium ions, protons are released, causing a decline in substrate $\mathrm{pH}$ (Argo and Biernbaum, 1997; Argo and Fisher, 2002; Pinton et al., 2007). In the current study, instead of increasing, the $\mathrm{pH}$ of the moss substrate in pots with a plant being fertilized with the high nitrate fertilizer (Phal.+/Fer.+) declined (Fig. 1A). Peng (2008) applied fertilizer solutions with various $\mathrm{NO}_{3}^{-}: \mathrm{NH}_{4}{ }^{+}$ratios $(0: 100,25: 75,50: 50$, 75:25, or 100:0) to Phalaenopsis plants potted in $\mathrm{SM}$ and found a lowering of $\mathrm{pH}$ in every treatment. Therefore, the type of fertilizer and the nitrate to ammonium ratio are not the main cause of substrate $\mathrm{pH}$ decline during Phalaenopsis cultivation.

Among the three materials used, the artificial moss had the highest initial $\mathrm{pH}$, which was followed by the bark mix and then the SM (Fig. 3A). The difference in $\mathrm{pH}$ may have to do with the cation exchange capacity (CEC) and base saturation of these materials. At a $\mathrm{pH}$ range of 3 to 4 , the CEC of SM is $26 \mathrm{meq} \cdot \mathrm{g}^{-1}$ (Kubota et al., 1993), whereas bark has a higher CEC of $100 \mathrm{meq} \cdot \mathrm{g}^{-1}$ (Pacific Wide Group, 2009). The higher CEC of bark means that it has more cation exchange sites. However, the bulk of the cation exchange sites in bark have been occupied by $\mathrm{Ca}^{2+}$ and $\mathrm{Mg}^{2+}$ ions added in the liming process by the manufacturer
(Pacific Wide Group, 2009), and thus fewer $\mathrm{H}^{+}$ ions are bound at these sites. Live SM has the ability to produce unesterified polyuronic acid (Clymo, 1964), and it grows in very acidic habitats; therefore, it is not surprising that the dried moss contains a large amount of exchangeable $\mathrm{H}^{+}$. The artificial moss is an inert material with limited CEC (Chang et al., 2006) that partly accounts for the highest $\mathrm{pH}$ observed among the three materials (Fig. 3A).

The bark used in this study was produced by the Pacific Wide Group. Its technical descriptions indicate a low $\mathrm{pH}$ of 3.5 in the raw bark. After aging treatments, its $\mathrm{pH}$ increased to 5.5 to 6.5 and is supposed to stay in that range for 9 months (Pacific Wide Group, 2009). This was not observed in this study and the $\mathrm{pH}$ of the bark also declined with time (Fig. 3A). Sphagnum moss is an organic material; therefore, $\mathrm{pH}$ change in SM substrate may be contributed by decomposition process. On the contrary, the artificial moss is a stable material with a near neutral $\mathrm{pH}$ that degrades very slowly. However, both $\mathrm{pH}$ of SM and the artificial moss started to decline significantly at the beginning of Week 3 (Fig. 3A), at the time new roots were observed to start growing. This indicates that the onset of substrate acidification may be closely associated with root growth.

Although fertilizer application and the nature of the substrate both contribute to substrate $\mathrm{pH}$ decline, they are not the major causes. Because $\mathrm{pH}$ declined in all pots with a plant in them regardless of which substrate was used and the decline in $\mathrm{pH}$ was slight in pots without a Phalaenopsis plant, it is clear that roots are the main contributor of substrate $\mathrm{pH}$ decline (Figs. 1A, 2A, and 3A).

Although the rate of acidification was different, the $\mathrm{pH}$ of the SM substrate dropped whether planted with a Phalaenopsis or an Oncidium (Fig. 4A). During the tissue culture of Dendrobium candidum, medium acidification started during the first 2 weeks of culture. In a study by Wang and Ha (2007), as time progressed, the $\mathrm{pH}$ of the agar medium dropped from an initial $\mathrm{pH}$ of 5.6 to a final $\mathrm{pH}$ of 4.2. Therefore, it is apparent that other epiphytic Orchidaceae species also possess the ability to acidify the rhizosphere.

Previous work showed that the decline in substrate $\mathrm{pH}$ is related to the absorption of minerals. Pinton et al. (2007) pointed out that under phosphorus (P)-deficient conditions, the roots of most dicots secrete carboxylates in exchange for P-complex to increase $\mathrm{P}$ absorption. In balancing the electrical charge inside and outside of the roots, $\mathrm{H}^{+}$is released to the substrate, resulting in acidification. When Zea mays is deficient of potassium, the root releases more sugars, carboxylates, and amino acids; for every carboxylate that the root releases, it also secretes a $\mathrm{H}^{+}$, resulting in $\mathrm{pH}$ decline in the rhizosphere (Kraffczyk et al., 1984). Some dicots, under low iron (Fe) conditions, release $\mathrm{H}^{+}$to the rhizosphere to activate the iron reductase on the cell membrane to increase the reduction of $\mathrm{Fe}^{3+}$ to $\mathrm{Fe}^{2+}$ for absorption (Strategy I); grasses release phytosiderophores (PS) through the ion channel simultaneously with $\mathrm{H}^{+}$, then take up metal-PS complex by specific transporters in the plasma membrane (Strategy II) (Pinton et al., 2007). Regardless of whether plants use Strategy I or Strategy II for increasing ion absorption, $\mathrm{H}^{+}$is released to acidify the growing substrate.

Although substrate acidification may be caused by root response to the lack of certain minerals in the rhizosphere, Lei (2007) reported that the SM substrate became acidified in two flowering cycles during which plants were given various ratios of $\mathrm{N}, \mathrm{P}$, and $\mathrm{K}$. However, when N, P, and K were not applied, the $\mathrm{pH}$ of the moss hardly changed and plants did not show symptoms of being deficient of minor mineral nutrients. Therefore, the acidification of the substrate, in which Phalaenopsis is planted, may not be caused by lack of mineral nutrients. The results of this study show that the roots of Phalaenopsis may be the main cause of substrate acidification, which may have something to do with how originally the epiphytic roots absorb mineral nutrients in their natural habitat. Growth of Phalaenopsis is normal in a substrate with low $\mathrm{pH}$; therefore, raising substrate $\mathrm{pH}$ may not be needed in the production of Phalaenopsis.

\section{Literature Cited}

Argo, W.R. and J.A. Biernbaum. 1997. Lime, water source, and fertilizer nitrogen form affect medium $\mathrm{pH}$ and nitrogen accumulation and uptake. HortScience 32:71-74.

Argo, W.R. and P.R. Fisher. 2002. Understanding $\mathrm{pH}$ management for container-grown crops. Meister Publishing, Willoughby, $\mathrm{OH}$.

Bureau of Foreign Trade. 2011. The export value of Phalaenopsis. 16 May 2011. <http://cus93.trade. gov.tw/fsci/>.

Chang, G.H., T.E. Dai, S.C. Huang, C.Y. Tsao, W.T. Tsai, F.N. Wang, A.H. Chang, and F.W. How. 2006. Application of artificial textile fiber as growing medium for Phalaenopsis cultivation. J. Taiwan Soc. Hort. Sci. 52:71-80.

Chen, C.L. 2006. Effect of fertilizer concentration on growth and flowering of Phalaenopsis hybrids. Master's thesis, Natl. Chiayi Univ., Chiayi, Taiwan.

Clymo, R.S. 1964. The origin of acidity in Sphagnum bogs. Bryologist 67:427-431.

Kollmeier, M., P. Dietrich, C.S. Bauer, W.J. Horst, and R. Hedrich. 2001. Aluminum activates a citrate-permeable anion channel in the aluminum-sensitive zone of the maize root apex. A comparison between an aluminum-sensitive and an aluminum-resistant cultivar. Plant Physiol. 126:397-410.

Kowalczyk, W., J. Dysko, and S. Kaniszewski. 2008. Effect of nutrient solution $\mathrm{pH}$ regulated with hydrochloric acid on the concentration of $\mathrm{Cl}^{-}$ions in the root zone in soilless culture of tomato. J. Element. 13:245-254.

Kraffczyk, I., G. Trolldenier, and H. Beringer. 1984. Soluble root exudates of maize: Influence of potassium supply and rhizosphere microorganisms. Soil Biol. Biochem. 16:315-322.

Kubota, S., T. Kato, and K. Yoneda. 1993. The effects of concentration of fertilizer application and the physico-chemical properties of sphagnum moss and clay pots on the growth of Phalaenopsis. J. Jpn. Soc. Hort. Sci. 62:601-609.

Lei, H.Y. 2007. Changes of mineral composition and fertilizer requirement of Phalaenopsis during reproductive stages. Master's thesis, Natl. Taiwan Univ., Taipei, Taiwan. 
Neumann, G., A. Massonneau, E. Martinoia, and V. Romheld. 1999. Physiological adaptations to phosphorus deficiency during proteoid root development in white lupin. Planta 208:373-382.

Pacific Wide Group. 2009. Orchiata technical data. 9 Feb. 2010. <http://www.orchiata.com/ productsheets.html $>$.

Peng, Y.C. 2008. The uptake, partitioning, and uses of nitrogen in Phalaenopsis Sogo Yukidian 'V3'. Master's thesis, Natl. Taiwan Univ., Taipei, Taiwan.

Pinton, R., Z. Varanini, and P. Nannipieri. 2007. The rhizosphere. 2nd Ed. CRC Press, Boca Raton, FL.

Sakaguchi, T., N.K. Nishizawa, H. Nakanishi, E. Yoshimura, and S. Mori. 1999. The role of potassium in the secretion of mugineic acids family phytosiderophores from iron-deficient barley roots. Plant Soil 215:221-227.
Tsai, P.F. 2000. Effect of temperature, photosynthetic photon flux, medium and fertilizer on growth of Oncidium. Master's thesis, Natl. Taiwan Univ., Taipei, Taiwan.

United States Department of Agriculture. 2010. National agricultural statistics service: Floriculture crops 2009 summary. 5 Feb. 2011. <http:// usda.mannlib.cornell.edu/usda/current/FlorCrop/ FlorCrop-06-04-2010_revision.pdf $>$.

Wang, M. and Y. Ha. 2007. An electrochemical approach to monitor $\mathrm{pH}$ change in agar media during plant tissue culture. Biosens. Bioelectron. 22:2718-2723.

Wang, Y.T. 1996. Effects of six fertilizers on vegetative growth and flowering of Phalaenopsis orchids. Sci. Hort. 65:191-197.

Wang, Y.T. 1998. Impact of salinity and media on growth and flowering of a hybrid Phalaenopsis orchid. HortScience 33:247-250.
Wang, Y.T. 2010. Phalaenopsis mineral nutrition. Acta Hort. 878:321-333.

Wang, Y.T. and E.A. Konow. 2002. Fertilizer source and medium composition affect vegetative growth and mineral nutrition of a hybrid moth orchid. J. Amer. Soc. Hort. Sci. 127:442-447.

Yao, H.Y. 2007. Applying pour-through medium solution testing method on Phalaenopsis grown with sphagnum moss. Master's thesis, Natl. Taiwan Univ., Taipei, Taiwan.

Yao, H.Y., R.S. Chung, S.B. Ho, and Y.C.A. Chang. 2008. Adapting the pour-through medium extraction method to Phalaenopsis grown in sphagnum moss. HortScience 43:21672170.

Yu, F.L. 2004. Effects of sphagnum moss, coir mix medium and enriched slow released fertilizers on the growth of Phalaenopsis. Master's thesis, Natl. Taiwan Univ., Taipei, Taiwan. 